\title{
Framing of Abortion and Church-State Relations in Russian Orthodox Online Portals
}

\author{
Caroline Hill
}

check for updates

Citation: Hill, Caroline. 2021.

Framing of Abortion and

Church-State Relations in Russian Orthodox Online Portals. Religions 12: 1084. https://doi.org/10.3390/ rel12121084

Academic Editors: Kristina Stoeckl and Dmitry Uzlaner

Received: 13 October 2021

Accepted: 4 December 2021

Published: 9 December 2021

Publisher's Note: MDPI stays neutral with regard to jurisdictional claims in published maps and institutional affiliations.

Copyright: (C) 2021 by the author. Licensee MDPI, Basel, Switzerland. This article is an open access article distributed under the terms and conditions of the Creative Commons Attribution (CC BY) license (https:// creativecommons.org/licenses/by/ $4.0 /)$.
Department of Theology, Institute for Russian and Eurasian Studies, Uppsala University, 75236 Uppsala, Sweden; caroline.hill@ires.uu.se

\begin{abstract}
Over the past two decades, clerics in the Russian Orthodox Church have found a new outlet for morality policy discussions: news portals, blogs, and other sites that comprise a virtual public sphere of Russian Orthodox online media. One prominent issue discussed herein is abortion in Russia, a subject that has spawned debates about possible regulation and prevention measures. This article analyzes statements regarding abortion made by clerics and others serving in the Russian Orthodox Church via Russian Orthodox online portals. Using typologies for framing strategies established through research of morality policy and church-state relations in Russia, this analysis will show that rational-instrumental frames were employed more frequently than religiously based or procedural arguments, and frames expressing affinity and disillusionment with the state were utilized more often than those evoking church-state symphony or anti-government disestablishment. In addition, it will shed light on framing strategies between online portals with varying degrees of proximity to the Moscow Patriarchate.
\end{abstract}

Keywords: Russia; Russian Orthodox Church; Orthodox Christian; morality policy; abortion; framing; media; mediatization; online

\section{Introduction}

In the years following the fall of the Soviet Union, clerics and others serving in the Russian Orthodox Church (hereinafter also referred to as the "ROC" and "Church") have become active participants in debates over morality policy issues in the Russian public sphere. One of the outlets by which these actors seek to communicate with the public is a range of religious news portals, blogs, and other web pages that will be collectively referred to here as Russian Orthodox online media.

When making arguments online regarding women's access to abortion in Russia, clerics and other speakers serving in the Church are forced to grapple with two major barriers. First, the majority of Russians are nominally Orthodox, meaning that church attendance and other common indicators of religiosity are comparatively quite low. Second, the early legalization of abortion and dominance thereof as an accepted form of birth control during the Soviet era created what has been termed an "abortion culture" (Johnson 2004; Karpov and Kääriäinen 2005; Rivkin-Fish 2017), meaning that pro-life arguments may be a harder sell to online audiences than the Church's stances in previous debates (such as those regarding so-called "gay propaganda" (Hill 2017) in the early 2010s, where the majority of the Russian population supported the ROC's position).

This article is an examination of statements made by Russian Orthodox clerics and others serving in the ROC via Russian Orthodox online media concerning regulation of access to abortion. Articles sourced from Russian Orthodox portals from 2000 through 2020 are subjected to a framing analysis, employing typologies based on prior research in morality policy and church-state relations in Russia. By doing so, the author hopes to contribute to studies of morality framing practices and attitudes toward the state in political science and political sociology. By focusing on the case of Russian Orthodox clerics and Russian Orthodox online media, the article intends to expand morality policy research 
toward including the analyses of a non-state actor-the Russian Orthodox Church-that is not often studied from this angle. Furthermore, by focusing on clerics and others serving in the Russian Orthodox Church and Russian Orthodox online media, the article seeks to contribute to research on the mediatization of Russian Orthodoxy within sociology of religion.

\section{Abortion in Russia}

In order to understand the approach of clerics and others serving in the Russian Orthodox Church to debates over abortion, one must first consider the history and culture surrounding abortion and women's reproductive health in Russia, from the Tsarist era onward. Under the pre-Revolutionary penal code, abortion was classified as murder and punishable by prison terms for physicians and time spent in a "house of correction" for women who sought the procedure for reasons other than saving their own life. This was revised by medical congresses starting in 1910, with advisories to spare women of punishment-but prosecute doctors "who performed abortions for purposes of greed" (Solodnikov 2010, p. 77). Nevertheless, intentional terminations of pregnancy were a common procedure by the time of the Revolution in 1917, as "abortions ... became a feature of not only the urban, but rural family [as well]" (Beliakova et al. 2011, p. 425) with "about 20 percent of pregnancies ended in abortions" (Karpov and Kääriäinen 2005, p. 17) prior to 1920, when the newly formed Soviet Union became the first country to legalize abortion (Johnson 2004, p. 202).

The legalization of abortion ushered in seven decades in which reproductive health policy was governed not according to public health concerns, but by material priorities of the Soviet state. This sometimes led to contradictory measures: although the government "considered abortion access necessary for emancipating women from the home and mobilizing them into the labor force ... they did not condone the limitation of births, and neither promoted contraceptives nor ensured their availability" (Rivkin-Fish 2013, p. 572), a practice that drove abortion rates up as women entered the command economy. In a drive to "create more workers and soldiers" (Johnson 2004, pp. 202-3) Stalin moved to ban abortion, a strategy that backfired as criminal procedures soared along with mortality rates among women who chose to risk black market abortions. After his death, abortion was legalized again, and legal termination figures rebounded, hitting a high of 2745 abortions for every 1000 live births in 1965 (Luehrmann 2017, p. 105). In 1990, on the eve of the Soviet Union's collapse, this figure had dropped, but abortions still outpaced live births by 206 to 100 (Sakevich and Denisov 2019, p. 142).

State medical institutions perpetuated the dominance of abortion as a preferred means of birth control. The Soviet Ministry of Health "discredited new contraceptive methods and prevented their introduction into the country" (Johnson 2004, p. 205) while medical personnel were tempted by financial perks such as funding tied to hospital occupancy rates, which made retaining patients for overnight stays after terminating pregnancies on flimsy grounds more attractive than sending them home with accurate medical advice. Even in the post-Soviet era, when the list of reasons for permitting later-term abortions was reduced for the first time in 2003 (Denisov and Sakevich 2014, p. 61), the state was preoccupied with its own finances- "Russia's health ministry [had] been spending five percent of its annual budget on funding free abortions" (Johnson 2004, p. 208), as requests for the procedure spiked again during the first decade of social and economic transition (Luehrmann 2017, p. 106).

It was not until 2007 that live births surpassed abortions performed in Russia for the first time since the Soviet period (Denisov and Sakevich 2014, p. 52). Although this ratio has continued to improve, for generations of Russian women, the Soviet health care system and post-Soviet economic chaos had already left their mark: three years earlier, it was determined that "the average Russian woman has had six to eight abortions in her lifetime, and it was not unheard of to have as many as eighteen" (Johnson 2004, p. 207) in a society bereft of alternatives where women ended unintended pregnancies in "clinics they 
described as factories or meat grinders ... and even without anesthesia" (Rivkin-Fish 2013, p. 573). When Russian Deputy Minister of Health Oleg Salagay announced a 30 percent decrease in abortions over the previous five years in 2020, he cautioned that "these are big numbers, serious changes, but the number of abortions still remains very high ... approximately 523,000" performed in 2019 (TASS 2020) in a country with a population estimated at 146 million (Federal State Statistics Service 2021).

These behavioral patterns have been described as "abortion culture" (Johnson 2004; Karpov and Kääriäinen 2005; Rivkin-Fish 2017), elaborated upon by Karpov and Kääriäinen as "the widespread and deep-seated view that abortion is a perfectly acceptable way of dealing with medical and socioeconomic hardships in personal and family life" (Karpov and Kääriäinen 2005, p. 14). Karpov and Kääriäinen attributed "its existence and persistence to the lasting demoralizing effects of communist rule" (Karpov and Kääriäinen 2005, p. 14) and "ruthless destruction of the nation's religious heritage (Karpov and Kääriäinen 2005, pp. 24-25). Beliakova et al. (2011, p. 427) made a similar link between the masses' loss of faith and the number of abortions performed, citing the "swift spread of the practice of the abortion" as an "expression of the decrease in religiosity" in the early years of the Soviet Union. Russia was anomalous when compared with levels of acceptance for abortion in other Orthodox Christian societies (including formerly communist Bulgaria; Karpov and Kääriäinen 2005, p. 24), and "even affiliation with and attendance at services of the increasingly influential Russian Orthodox Church" had no discernable effect on citizens' opinions regarding the acceptability of abortion, as "Russians who identify themselves as Orthodox do not differ in this regard from atheists, and church attendance only slightly increases the likelihood of a principled opposition to abortion" (Karpov and Kääriäinen 2005, p. 29).

During the Soviet era, the ROC was actively prevented from making counter-arguments to abortion culture: according to Flood (2002, p. 210), “No autonomous groups or even individual voices were allowed to initiate public debate on value-related subjects, including abortion. The Orthodox Church, battered and intimidated by repeated waves of official hostility, kept quiet for many years". While there were some rumblings within the Soviet medical establishment after legalization pertaining to the safety of the procedure, there was no room for moral arguments, from the Church or anyone else:

... In the official discourse, the problem of abortion was framed as either a social-policy or a medical problem, but not as a moral issue, and certainly not as a religious one. In addition, any attempts to evaluate the social policies and practices from a religious perspective could result in repression ... conceptual tools for such thought were simply missing (and often forcibly excluded). (Karpov and Kääriäinen 2005, p. 21)

While attempting to rid Russian society of Soviet-era habits was a daunting task, the ranks of those permitted to speak about abortion swelled after 1991, as the floodgates of communication opened, and a host of actors previously forbidden from entering the public sphere "such as private health care providers, Western pharmaceutical companies, commercial mass media, international foundations and agencies, new nongovernmental organizations and the Russian Orthodox Church—began to play a role in family planning" (Regushevskaya et al. 2009, p. 51). The ROC took note of this development and quickly set about establishing itself as a prominent cohort in what became known as the prolaif (pro-life) movement (Luehrmann 2019, p. 774).

A crucial moment in this process came in 2000, with the release of The Basis of the Social Concept of the Russian Orthodox Church (hereinafter referred to as "The Basis of the Social Concept"), a document adopted by the Council of Bishops of the Russian Orthodox Church that set forth the ROC's official stance on multiple social issues, from churchstate relations to war to abortion (Russian Orthodox Church 2008). Under Section XII, "Problems of Bioethics", it was declared that "the Church views intentional termination of pregnancy (abortion) as a serious sin. Canonical rules equate abortion with murder" (Russian Orthodox Church 2008). 
The publication of The Basis of the Social Concept kicked off a new pattern of interaction with the general public and the Russian state that established the ROC as a "moral norm entrepreneur" (Stoeckl 2016, pp. 132-3). The primary focus of the ROC's external communications shifted from "the Church itself-its place in society, religious education in schools and the military, church entitlements and privileges, restitution of property and religious artefacts taken away from the Church during Communism" to a new interest in "issues of social ethics and public morality: family, abortion, and demographic change" (Stoeckl 2020, p. 45).

One avenue for this outward focus is the involvement of Orthodox clerics and others serving in the Church (such as Abbess Kseniya (Chernega), the chief of the Moscow Patriarchate's Legal Service) in lobbying the state to make changes to legislation, including laws governing access to abortion. The results have been mixed at best. While amendments to the federal law on healthcare passed in 2011 included a mandatory waiting period and protections for conscientious objection by physicians who refused to perform abortions (Ministry of Health of the Russian Federation 2011), other proposals, such as a push for abortions to be excluded from the country's state-funded mandatory medical insurance program (hereinafter referred to by its Russian acronym, the OMS), have fallen short, making it "thus far, one of the least successful legal avenues in the [C]hurch's consistent attempt to turn its pro-life position into secular legislation" (Ponomariov 2021, pp. 247-8).

Convincing the Russian public to let go of abortion as an acceptable birth control method has proven to be much more of a challenge than other ROC lobbying initiatives. While framing of bans on public expressions of LGBT identity often touched upon the fact that the overwhelming majority of the Russian population approved of such restrictions (Hill 2017), public opinion regarding abortion is far more complex. According to the Levada-Center (2018), 81 percent of those polled condemned same-sex relationships; in contrast, only 35 percent said the same about abortion. Although this figure has trebled from a mere 12 percent in 1998 (Levada-Center 2018), the combination of the fact that abortion was the default birth control method for decades and the low percentage of practicing Orthodox Christians among the nominal masses presents a challenge to those serving in the Church when addressing the issue of abortion in the public sphere, including the Russian Orthodox online media space explored here.

\section{Morality Policy}

In order to analyze arguments used within Russian Orthodox online media regarding abortion in Russia, a typology based on prior research in morality policy was used. Morality policy started as the study of a substantial category of policies centered around "questions of first principle", or "the legal sanction of right and wrong, the validation of a particular set of basic values" (Mooney 1999, p. 675) that govern issues of "life, death, sex" (Hill 2017, p. 13) and other sensitive topics that can range from abortion to gun control, depending on the country where these debates arise. Studlar $(2008$, p. 394) expanded the scope of morality policy to "'blended' issue[s] ... that can take on economic and public health, as well as morality dimensions, depending on successful agenda setting and framing by interest groups", thus creating a link between morality policy and framing research.

This development was expanded upon by Mucciaroni (2009), who encouraged an approach of "systematic examination of the arguments that advocates actually put forward" in order to determine if morality policy debates were truly about "deontological principles", or if they concerned "social consequences" for the greater public or "procedures" that should be followed to remedy an issue (Mucciaroni 2009, pp. 13-14). This typology of arguments was refined in Mucciaroni's 2011 study of framing of homosexuality by opponents of LGBT rights in US legislatures, where he differentiated between "morality talk", or frames pointing to "the morality of private behavior by calling attention to moral and religious disapproval" of certain activities, rational-instrumental frames "calling attention to the negative consequences for society, or some important part of it" (Mucciaroni 2009, p. 195) and framing in "procedural terms-talking about how decisions should be made, 
which level of government or institution should make them, and whose preferences should be weighed most heavily" (Mucciaroni 2009, p. 198; original emphasis).

Although Mucciaroni's studies concerned framing in legislative debates, he called for morality policy research to expand "beyond examining the frames employed by legislative advocates by looking at how other opponents, including interest group leaders, activists, and citizens, frame typical morality policy issues" and surmised that "we might expect these other actors to engage in morality talk more often than legislators" (Mucciaroni 2011, p. 212) due to the fact that this framing would target existing group members rather than outsiders. Kettell's study of collective action frames used by conservative Christian groups in Britain similarly noted this insider-outsider dichotomy and split framing strategies into those targeting "'internal' and 'external' sets of audiences" (Kettell 2017, p. 287) defined in broad terms as those belonging to these groups and outsiders. They concluded that, in the pursuit of influence in a society "with religion ... declining across all key measures of religiosity, conservative groups have increasingly turned to the use of collective action frames based on overtly secular norms and values rather than theological assertions" (Kettell 2017, p. 288).

In the Russian context, questions of framing in morality policy debates and intended audiences are salient due to the particular nature of religious self-identification versus actual religious observance in the country. While the percentage of Russians that selfidentify as Orthodox Christians has risen from 33 percent in 1990 to 68 percent in 2020 (Levada-Center 2020), the percentage of what Yemelyanov (2018, p. 35) called "practicing Orthodox Christians", defined as "those who take Communion once per month [or] more" (Yemelyanov 2018, p. 44), has hovered around 3 percent. For this reason, even media aimed at Orthodox Christian audiences must be sensitive to the realities of nominal religious identity after decades of repression.

The results of a frame analysis of materials from online portals indicated that when speaking to mainstream secular and Russian Orthodox media outlets about bans on public displays of so-called "gay propaganda", ROC clerics employed more rational-instrumental than religious-moral frames; even when clerics were interviewed in person at their home parishes, rational-instrumental framing prevailed (Hill 2017, pp. 55-56). Staehle (2018a, p. 83) reported similar observations regarding Patriarch Kirill's use of "secular language, taking inspiration from public relations strategies rather than from Scripture" when speaking in support of an increased public presence for the Church. Strategic use of "the language of human rights" in debates over morality policy issues was also noted by Stoeckl (2020), who attributed this marked "shift in communicative strategy" both in terms of content and framing to "a relatively small circle of clerics around Kirill, working inside the Moscow Patriarchate's External Relations Department" (Stoeckl 2020, p. 45), the ROC's foreign relations office.

In the case of abortion, religious framing that has proven successful elsewhere may fall flat in Russia. Mason (2019) noted that "the scare tactic of saving the soul of the nation before the return of Jesus Christ" that had previously resonated with Evangelical Christian circles in the US would not translate well into the Russian context, "because atheism was state policy in the Soviet Union" (Mason 2019, p. 678) for decades; "instead, the contemporary Russian antiabortion narrative is about losing the nation to those who may outbreed the Russians" (Mason 2019, p. 679), thus appealing to xenophobic sentiments and anxiety over demographics. Even when speaking to Russian Orthodox audiences, frames based in religion may not succeed: the fact that prior research has shown that even participation in the life of the Church may not preclude lax attitudes toward abortion (Karpov and Kääriäinen 2005) indicates that those communicating the Church's stance need to choose their words carefully in order to reach audiences still influenced by the legacy of the Soviet health care system. 


\section{Materials and Methods}

In order to determine which arguments public speakers in the ROC use, a frame analysis using typologies from previous studies of the Church was applied. Hill (2017) adjusted Mucciaroni's (2011) morality policy framing typology to the Russian context by doing away with the distinction between moral frames as private and rational-instrumental frames as pertaining to public concerns; instead, a religious-moral frame was created that could "apply to religious and moral strictures on the private lives of individuals as well as public spaces and social life" (Hill 2017, p. 25). Rational-instrumental frames were defined as applying "not only to society-level issues, but to material issues as applied to private individuals' lives-areas such as genetics, psychology, and medicine", while "procedural" frames assessing the work of government officials and calling for further action rounded out the trio (Hill 2017, p. 25). In this analysis, the religious-moral frame was narrowed down further to being simply religious (in order to exclude references to Soviet-era, non-religious moral codes), while the other morality policy categories were kept as is.

In addition to determining which of the morality frame types was most prevalent, this study sought to expand upon the ways in which the speakers quoted framed the behavior of the Russian state and the Church's interactions therewith through procedural framing. In this case, the author drew upon Stoeckl's (2018) models of church-state relations, gleaned from research of Russian Orthodox conservative actors. Stoeckl identified "three levels of political activism within the Church: the Moscow Patriarchate, activist priests, and various activist groups of believers" (Stoeckl 2018, p. 221). The stances of these three cohorts vis-à-vis the Russian state were categorized in three models: symphony, wherein the ROC acts as "an exclusive partner of the state and the representative of the majority of the Russian people"; cooperation, wherein the ROC is but one of "public religions, having equal rights with [other faiths]"; and disestablishment, wherein the ROC performs in the role of an "antagonist of the state" (Stoeckl 2018, pp. 234, 238, 239).

In the context of this article, Stoeckl's (2018) models are adapted into frames of how ROC actors view the behavior of and the Church's relations with the Russian state and representatives thereof-including personnel of state-run medical institutions. The first, and most congenial, is a symphony frame, referring to the concept of symphonia, "a traditional principle of Eastern Christianity, first formulated in Justinian's Codex Juris Canonici, meaning close interaction of secular and sacred authorities in a Christian society" (Agadjanian 2001, p. 357). While the ROC acknowledges in The Basis of the Social Concept that "symphony didn't exist in an absolutely pure form in Byzantium", the document goes on to state that "relations between church and state powers in Russian antiquity were more harmonious" (Russian Orthodox Church 2008).

In the post-Soviet context, symphony has become "a favorite notion used by journalists with reference to the state-church relationship" (Agadjanian 2001, p. 357) and an ideal type for favorable relations between the ROC and Russian state. Patriarch Kirill's "vision for [symphony's] implementation in the Russian Federation", which Ponomariov (2021, p. 237) dubbed "reloaded" and "reinvented" symphony, is one in which the ROC and state would "respect each other's position ... and, at the same time, build a wide-range interaction, dialogue, and cooperation" (RIA Novosti 2009). The element of cooperation set forth by Patriarch Kirill is essential to the symphony frame type used here, applied to speech promoting or expressing approval of church-state initiatives such as installation of clerics in state-run institutions-for example, as counselors in state medical clinics as part of abortion prevention efforts, or as consultants and co-authors when drafting legislation restricting abortions.

The second frame type, dialogue, is divided into affinity and disillusionment frames, depending on the speaker's assessment of state policy. These apply in cases where the Church is not embedded or attempting to embed itself in the work of state authorities as in the symphony frame, but providing positive or negative commentary on the functioning of the state and state-run institutions and delivery of services thereby. Affinity frames 
could apply to favorable assessments of benefits awarded to larger families and vulnerable single mothers, for example, while the disillusionment framing type refers to expressions of disappointment by ROC actors regarding perceived failures by the state, such as inadequate support to large families, broken promises surrounding provision of social welfare benefits, and the hostile behavior of lower-level civil servants and staff of state-run OB-GYN clinics and maternity hospitals. Because many ROC clerics and others serving in the Church have families with multiple children, these anecdotes are often borne of personal experience.

The third church-state framing type, disestablishment, applies to situations where those serving in the Church view the Russian state as acting in ways that are harmful to the public to such an extent that ROC-state interactions are no longer deemed prudent, and the state is framed as an enemy of or existential threat to the people. The frame's namesake is Stoeckl's (2018) model of grassroots Russian Orthodox movements that "find support on the part of the Church hierarchy" and behave in a manner befitting participants in a "'culture war' with state bureaucracy and the majority of society" (Stoeckl 2018, p. 239). This stance was embodied by one of Luehrmann's (2017) pro-life activist respondents, who openly declared that their center's work was "anti-state activity ... the state permits abortions, and we fight against them" (Luehrmann 2017, p. 103). The fact that such activists work with the blessing of a segment of the Orthodox clergy indicates that "personal symphony" (Ponomariov 2021, p. 252) between Patriarch Kirill and Russia's leadership does not necessarily trickle down to the level of local parishes. This study is therefore also a test of how those serving in the Church and speaking publicly choose to describe their relationship to the Russian state, and how far they might go in expressing displeasure therewith in a Russian Orthodox online milieu.

\section{The Sample}

In order to solve the puzzle of how clerics and others serving in the ROC approach the complicated topic of abortion in the public sphere, the author decided to explore framing used when addressing this topic via Russian Orthodox online media sources, a subset of what Hjarvard $(2012,2016)$ defined as "religious media" within the field of mediatization of religion. While Hjarvard contends that religious groups, ideas, and practices have "become increasingly dependent on the media" and that the latter has even "taken over many of the social functions of the institutionalized religions" (Hjarvard 2008, p. 19), religious media can be a forum for religious institutions and individuals to promote their beliefs without being "subordinated" and forced to "comply with generic conventions" of mainstream media (Hjarvard 2016, p. 10).

In the case of the Russian Orthodox Church, communicating via mass media sources, and online media sources in particular, has been a crucial initiative to "address not only Orthodox Christians but society at large" that started in the 1990s with the expansion of the Internet in Russia, and intensified in the wake of Patriarch Kirill's 2009 enthronement (Staehle 2018a, p. 386). Although the Church's support of the growth of Russian Orthodox online media may be due in part to a distrust of "non-Orthodox media as lacking authenticity, credibility and reliability", the actual "media logic" of Russian Orthodox online portals may be more similar to non-religious Web pages than one might expect (Staehle 2018a, p. 389). For this reason, speakers could still be beholden to the conventions of mainstream media, wherein "a rational kind of authority tends to dominate" at the expense of arguments "with reference to religious sentiments and beliefs" (Hjarvard 2016, p. 14).

The sample was created by employing a keyword search for a 20-year period starting in 2000 on the pages of four independent Russian Orthodox portals: Pravoslavie.Ru (Pravoslavie.Ru), Foma (hereinafter Foma.Ru), Pravoslavie i Mir (Pravmir.Ru), and Russkaya Narodnaya Liniya (Ruskline.Ru). The year 2000 was selected as the start date of the analysis because it was the year when the Russian Orthodox Church released The Basis of the Social Concept. The four portals were selected due to their use in prior surveys of Russian Orthodox online media (Bogdanova 2020; Bogdanova and Sokolov 2020; Grishaeva 2020; Grishaeva and Shumkova 2018; Luchenko 2015; Ponomariov 2015; Staehle 2018a), and their 
varying degrees of proximity to the Moscow Patriarchate as an institution. Comparing the framing strategies used was also a test of how clerics and others serving in the Church conformed to each portal's overall tone. As Grishaeva put it, "any statement published in a given Orthodox medium is the author's statement, but at the same time it fits into a certain ideological frame that has been selected by the editors" (Grishaeva 2020, p. 241).

The Pravoslavie.Ru portal is run by the Sretenskiy Monastery in Moscow, placing it under the direct supervision of a Church institution. The co-founder and editor-in-chief of the Foma.Ru portal is Vladimir Legoyda, chairman of the ROC's Synodal Department for Church Relations with Society and Mass Media and interim leader of the Press Service of the Patriarch of Moscow and all Rus; while Legoyda is a layman, this nevertheless shows a human link between the portal and Church structures. A study of Foma.Ru stated that the goal of the site was "maximum coverage and engagement of the audience; that is, the number of readers of selected materials and the number of those who become a loyal reader ... forming a core audience" (Bogdanova and Sokolov 2020, p. 79). The observation that nearly 40 percent of those who submitted questions to a clerical Q\&A rubric of the Foma portal either rarely attended or visited churches, did not visit churches at all, or were atheists/non-believers indicates that clerics and others called upon to comment on morality policy issues via this source would have to structure their arguments in ways that would be palatable to those with little personal connection with the Church and its tenets (Bogdanova 2020, p. 216).

Pravmir.Ru is headed by a laywoman, Anna Danilova; while Archpriest Aleksandr Ilyashenko, one of the clerics quoted in this article, was a co-founder and spiritual father of the portal (RIA Novosti 2019), he later discontinued support of the portal, and was supported in this move by Deputy Chairman of the Synodal Department for Church Relations with Society and Mass Media Vakhtang Kipshidze, who expressed concern regarding the portal's content and "conformity ... thereof [with] Orthodox mass media sources" (Pravoslavie.Ru 2019). These events place Pravmir.Ru at a greater distance from the nucleus of the Moscow Patriarchate as an institution, while at the same time it has been described as "an invaluable source when it comes to the analysis of debates within the Orthodox community" (Staehle 2018b, p. 20).

Ruskline.Ru is similarly run by laypeople, and has been characterized by Grishaeva as "at the periphery" of the Moscow Patriarchate as an institution (Grishaeva 2020, p. 244). However, Grishaeva also noted that "from time to time pravoslavie.ru republishes materials from ruskline.ru and vice versa", which she cited as evidence of "the ideological proximity of the two resources" (Grishaeva 2020, p. 244). The comparison of these and the other online portals was thus also a test of the extent to which framing strategies might overlap between online sources. There were also signs in prior research of a tendency toward rational-instrumental framing in Ruskline.Ru articles: "anti-Western criticism becomes politicized, and the moral and religious agenda is of secondary concern. Using strong and offensive language the authors frame the West through a geopolitical discourse that reveals their nationalistic position" (Grishaeva 2020, p. 236).

Actors whose framing practices were analyzed were either clerics (the overwhelming majority, with 156 quoted in or authoring the articles analyzed) or others serving in the church (two speakers: ROC legal chief Abbess Kseniya (Chernega), and Subdeacon and Russian State Duma Deputy Vitaliy Milonov). In all, 471 articles were gathered (see Figure 1). 


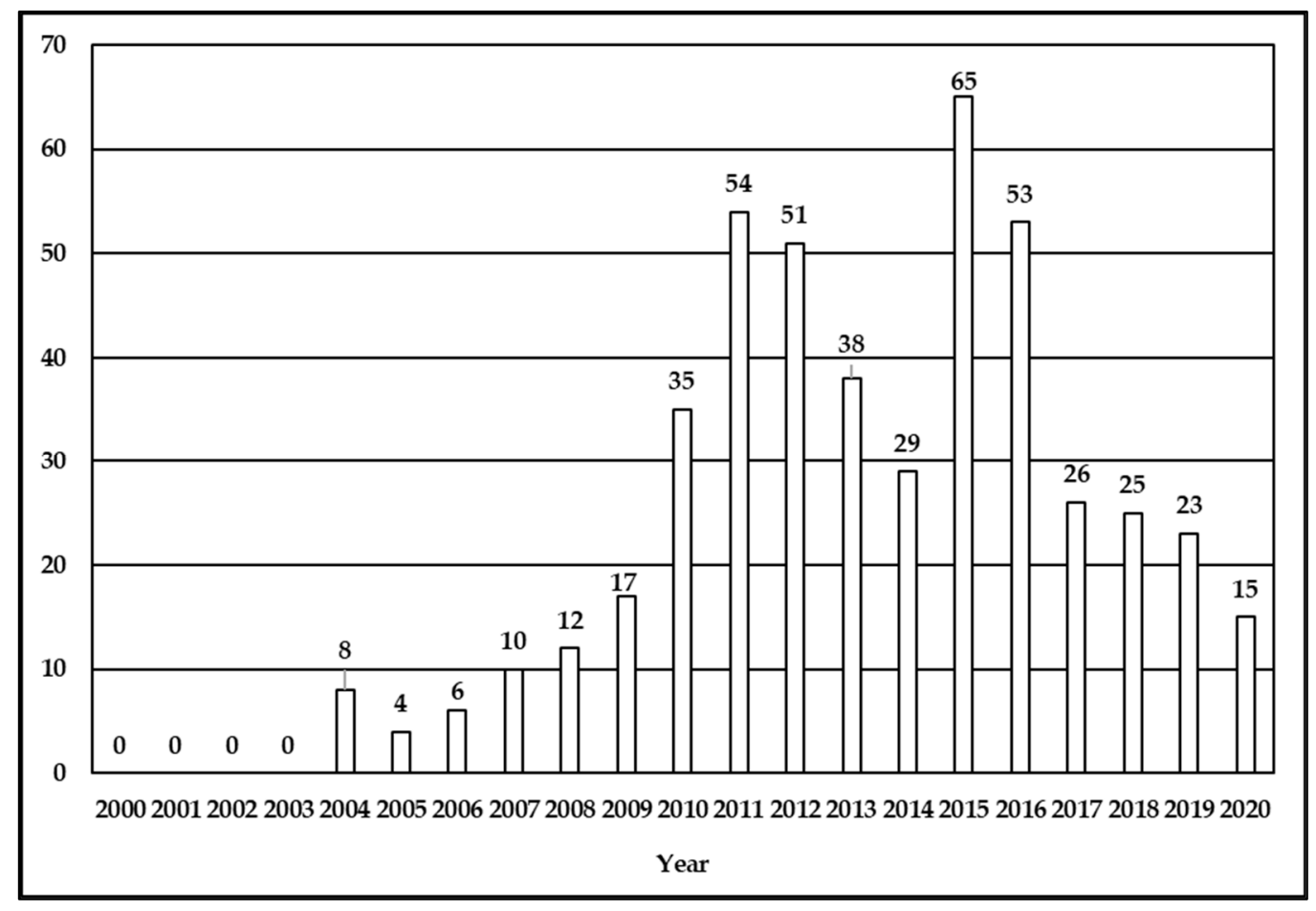

Figure 1. Articles by year, number of articles.

A deductive analysis was performed using NVivo software in order to determine the frequency with which the morality policy frames defined by Mucciaroni (2011) and adjusted to the Russian context by Hill (2017) and the framing typologies adapted from Stoeckl's (2018) church-state relations models were employed. An inductive analysis was also conducted in order to find relevant sub-frames, following Mucciaroni et al.'s (2019, p. 182) grouping of "separate, but related, frames under what we call broad dimensions or "meta-frames'" when tracking framing of abortion. In this study, Mucciaroni (2011) and Hill's (2017) morality policy frames served as meta-frames, with themes grouped within as sub-frames. Morality policy frames and church-state relations frames were counted for each category in every article in order to determine which frames were used the most frequently and therefore considered "dominant" (Hill 2017, p. 27). The dominant frames for each article were counted again for each portal in order to determine if framing strategies differed between portals.

During the coding process, "borderline" terms were identified that could be "applicable to two or more framing strategies, depending on the overall context of the sentence" (Hill 2017, p. 26). In this study, the words "murder" (ubiystvo) and "crime" (prestupleniye) stood out in that they could be religious or rational-instrumental. This was further complicated by the idea that "in the opinion of legal scholars, the categorization of abortion as 'murder' in the majority of modern legislation has its root[s] in canon law, which was unacceptable for Soviet jurisprudence and medicine" (Grafova 2020, p. 235).

As in Hill's (2017) study, it was decided to avoid coding such terms on their own or based on the potential ideas or motivations behind them, but rather to judge them based on "the presence or absence of certain keywords, stock phrases, stereotyped images, sources of information, and sentences that provide thematically reinforcing clusters of facts or judgements" (Entman 1993, p. 52). According to this system, the word "murder" used in conjunction with Biblical themes, such as the Holy Innocents slain by King Herod in Bethlehem (Matthew 2:13-23 NKJV) was coded as religious, as it would resonate with readers who fit Yemelyanov's definition of "practicing Orthodox Christians" (Yemelyanov 2018, p. 35) as opposed to nominal Orthodox with a weak grasp of Scripture. If it appeared in clauses referring to the human toll of World War II on the Soviet Union, on the other 
hand, it was coded as rational-instrumental, as it would stir emotions in a wider, nominally or non-religious swath of the Russian public.

\section{Results}

In this section, the results will be presented by framing type: first, by the morality frames employed, and second, by church-state relations frames. These will be compared between the portals studied, and the ways in which the frames were used in arguments regarding abortion will be presented in detail.

\subsection{Morality Framing}

Of the 471 articles gathered, 454 quoted Russian Orthodox clerics and others serving in the Church using morality frames. The analysis showed that of these articles, 50 percent had a dominant rational-instrumental frame, with religious dominant frames coming in second at 38 percent; those with procedural frames garnered only 12 percent (see Figure 2).

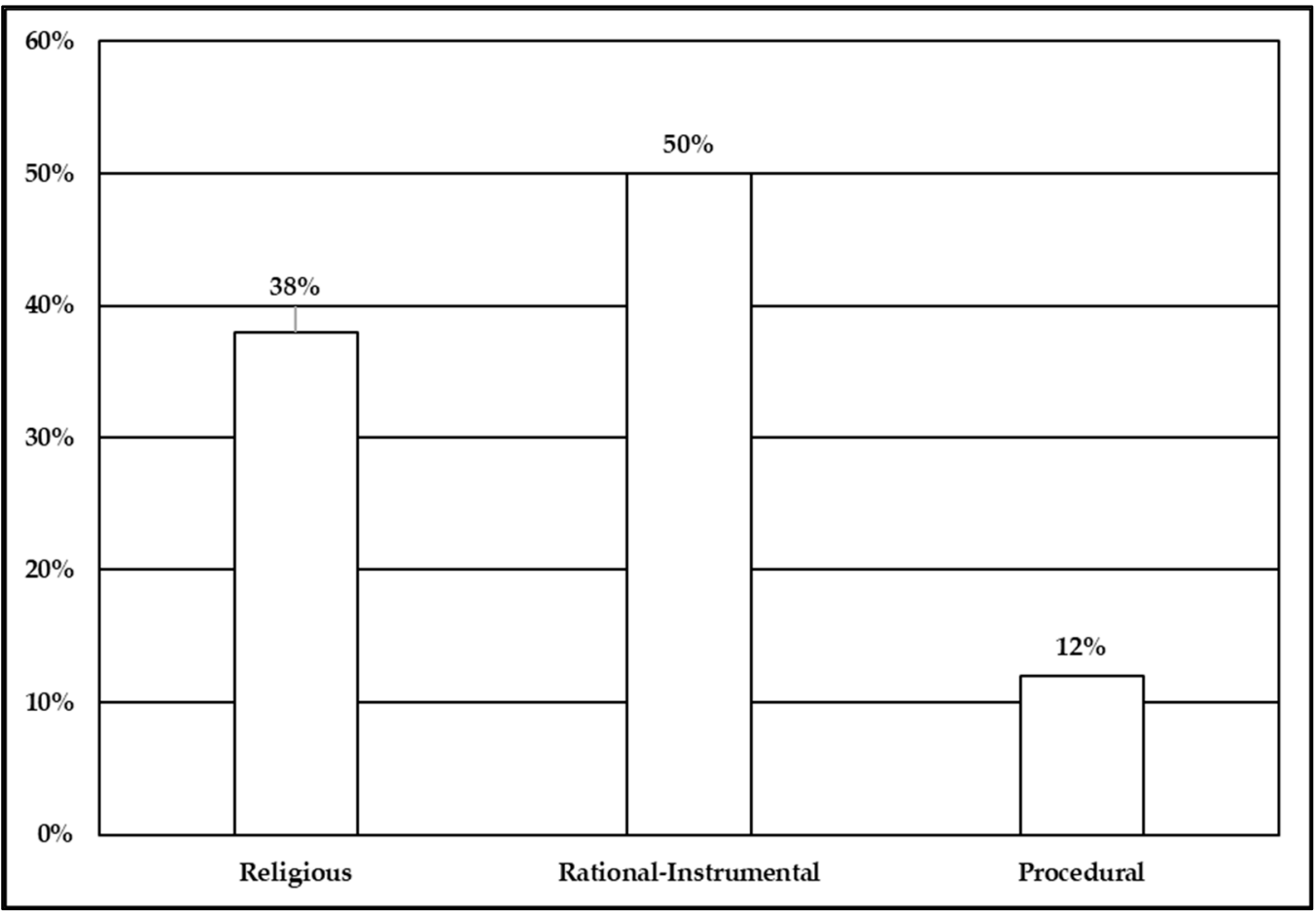

Figure 2. Dominant morality policy frames, percentage (\%) of articles where found.

Of the articles published on Pravoslavie.Ru, the majority (49 percent) had a rationalinstrumental frame, with religious frames taking a close second with 41 percent, and procedural frames with 10 percent. In the case of the Foma.Ru articles, rational-instrumental dominant frames had a greater majority with 65 percent, with religious frames lagging in second at 26 percent, and procedural frames at a mere 9 percent. Articles posted on Pravmir.Ru also showed a clear majority of rational-instrumental dominant frames with 54 percent, followed by religious frames in second with 33 percent, and procedural frames capturing 13 percent. The articles from Ruskline.Ru were the exception, as religious dominant frames led with an overwhelming majority of 80 percent, while procedural frames were in a distant second place with 15 percent, and rational-instrumental frames held 5 percent (see Figure 3). 


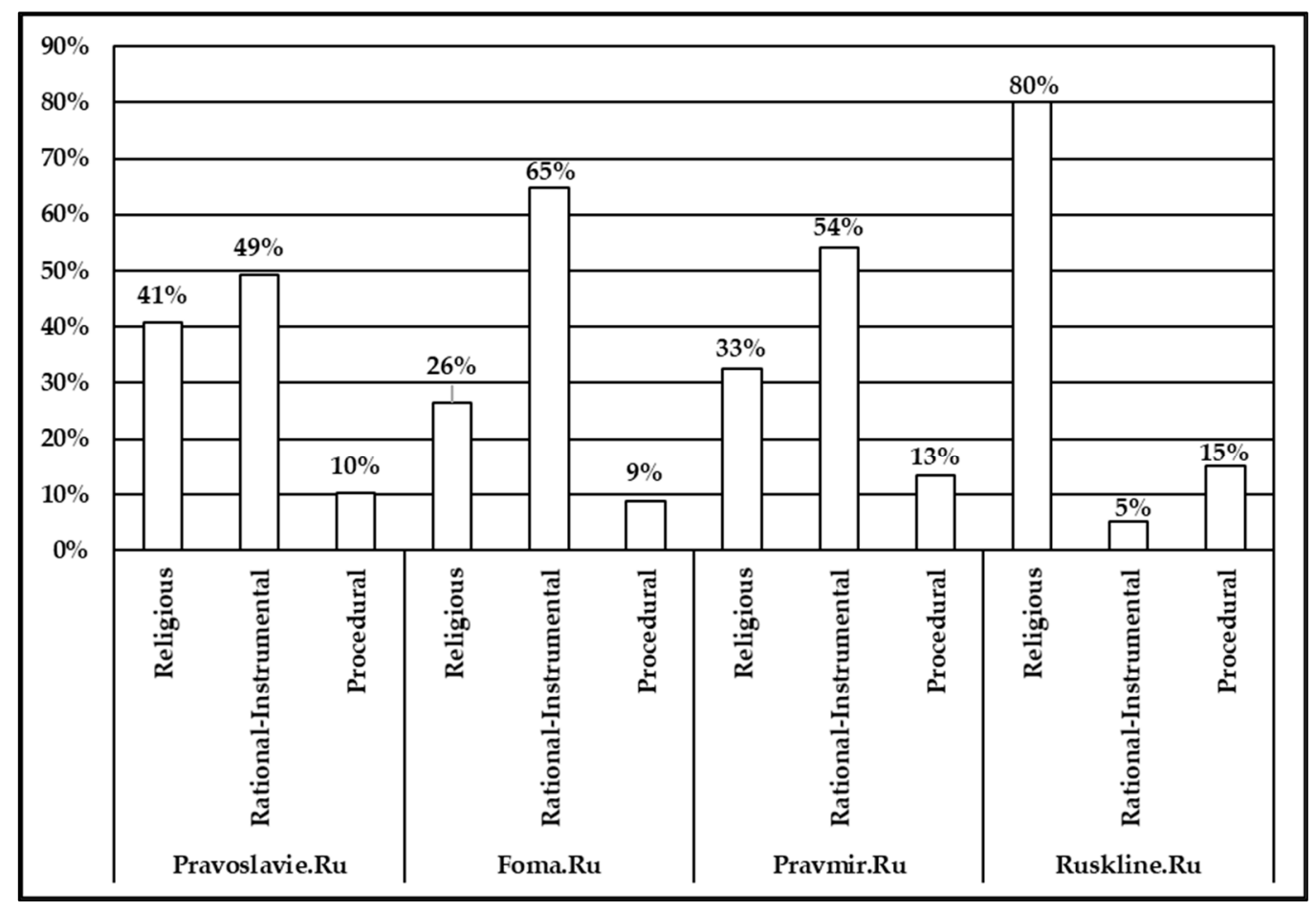

Figure 3. Dominant morality policy frames, $\%$ of articles where found by portal.

\subsection{Religious Frames}

Religious frames focused primarily on abortion as a sin, the Russian Orthodox Church, and its role in Russian society, references to God, abortion as murder, and morality couched in religion. Those who identified abortion as a sin often referred to it as part of a larger constellation of a person's relationship with religion: Archpriest Andrey Ovchinnikov stated that "Abortion is a mortal sin for which a person will suffer ... a person's relationship to abortions is a kind of test of his faith" (Selinov and Ovchinnikov 2016). Abortion in Russia was characterized as a national spiritual affliction: Priest Daniil Goryachev remarked, "This is our general sin, the sin of the entire people" (Akhundova and Goryachev 2015).

Frames invoking the Russian Orthodox Church most often called attention to the ROC's role as a moral authority in Russian society and a counterbalance to information flows that could sow immorality. Priest Vladimir Dukhovich claimed, "People are now pelted by information flows urging [them] to live for oneself, for one's own gratification. In these conditions, the voice of the Church, witnessing to Truth, is very important" (Yerakhtina 2013). Clerics also commented on the largely nominal character of Orthodox Christianity in Russia, and the ROC's attempts to bring change. Priest Dimitriy Lin proclaimed that "the problem of abortion is most of all a problem of spiritual enlightenment ... the task standing before the Church is the spiritual enlightenment and self-realization of our 'nominal Christians' as actual Christians"' (Russkaya Narodnaya Liniya 2016).

References to God pointed to divine intervention in the processes of conception and motherhood, and abortion as an affront to God's plans. Archpriest Aleksandr Ilyashenko argued that "the Lord bestows the gift of birthing children to a woman ... and to act against one's own nature is to act against the Lord God Himself" (Ilyashenko 2008). This frame was also used to create a clear distinction between the rights of the mother and God's will: Priest Oleg Bulychyov stated, "Women must understand that children are not their property. They have no right to do what they please with them. After all ... women are the means or mechanism by which God creates a person specifically for Himself" (Bulychyov 2014a).

The number of abortions performed in defiance of divine provenance was considered grounds for collective penalties at God's hands. Archbishop (now Metropolitan) of Ufa 
and Sterlitamak Nikon (Vasyukov) declared that "a country where infanticide is officially allowed is doomed to God's wrath; it's just a matter of time, one cannot save oneself from the Lord's punishing hand, not even with nuclear weapons" (Metropolitan of Ufa and Sterlitamak Nikon [Vasyukov] 2006). The prospect of impending divine punishment was used as a reason to press for change in Russian society. Archpriest Dimitriy Smirnov opined, "Cannibals like our people need to be wiped off the face of the earth, and only the enormous mercy of God toward us (because we are all His children) saves us from God's wrath. But if we don't wake up, God's fury will fall upon us" (Pravoslavie.Ru 2016a).

Framing of abortion as murder was accompanied (and distinguished from rationalinstrumental framing of abortion as murder) by references to Biblical scenarios of homicide or mass infanticide. Archpriest Aleksandr Ilyashenko compared negative psychological after-effects of abortions to the Old Testament story of God placing a mark on Cain as punishment for the murder of his brother Abel (Genesis 4:8-15 NKJV): “God punished Cain, [who] killed his brother Abel, [by] placing a seal on his face ... the soul of a person who has committed a murder is clouded to such an extent that it affects their external appearance ... abortion is always murder, [and] changes a woman's internal and external state" (Ilyashenko 2004a). The number of abortions performed in Russia was compared with the Holy Innocents slain by King Herod in Bethlehem as described in the Gospel of Matthew (Matthew 2:13-23 NKJV). Archpriest Igor Fomin proclaimed that "indeed, we are branded with the disgrace of Herod ... according to one appraisal, 20 to 30 children were murdered in Bethlehem ... Here in Russia, around 1.5 million abortions are performed in a year" (Fomin 2010).

Frames involving morality based in religion (as opposed to parallel systems of ethics established during the Soviet era) pointed to immorality in Russian society as the cause of the number of abortions performed in the country. Metropolitan of Volokolamsk Ilarion (Alfeyev) warned that "peoples multiply as long as strong moral foundations are preserved ... [at present], these institutions are suffering a massive attack by secular ideology ... as a result, an unprecedented number of divorces, abortions, incomplete families, crippled human fates, lives lost" (Metropolitan Ilarion [Alfeyev] 2011). Initiatives to spur a spiritual renaissance were sometimes favored in lieu of actions by the state: Hegumen Germogen (Ananyev) opined that "As long as a person doesn't understand that he is ... sinning and committing crimes, prohibitive measures won't help ... it is necessary to first turn to moral upbringing and spiritual education" (Russkaya Narodnaya Liniya 2010).

\subsection{Rational-Instrumental Frames}

Rational-instrumental frames mostly centered on the number of abortions performed in Russia, abortion as murder, the country's demographics, law, social attitudes, and medicine and the country's health care system. Commentary regarding the number of abortions performed often used the human toll and legacy of World War II (known as the Great Patriotic War in Russia) as a benchmark by which to measure abortion statistics-and shame society at large. Archimandrite (now Bishop) Panteleimon (Shatov) proclaimed, "We, the people of one of the greatest cultures of the world, who conquered fascism, live in a country where more than three thousand unborn children are killed every day" (Pravmir Editorial Staff 2010a). Hiermonk Dimitriy (Pershin) declared that "Abortions in our country mow down more people than those who perished on the front of the Great Patriotic [War] ... in the years of freedom from the ideology of pro-abortion Soviet nihilism, we have destroyed a number of people equal to the population of Ukraine" (Pravmir News Service 2014).

In addition to referencing casualties suffered in World War II, frames of abortion as murder invoked memories of more recent events, such as terrorist attacks within Russia's borders. Priest Oleg Bulychyov queried "when so many tears were shed and anger spilled forth over the murder of 186 children in Beslan, why did nobody sigh over or remember the 15 thousand infants killed in abortion clinics (in Russia alone, according to statistics) the very same day? ... modern humanity, calmly killing its own children, is the main bloody 
terrorist" (Bulychyov 2014a). Archpriest Dimitriy Smirnov contrasted many Russians' laissez-faire attitude toward abortions with horrified reactions to news coverage of events unfolding in Syria: "When children are killed in Aleppo, they understand that this is bad, but when [children] are killed in maternity wards, this is taken for granted. Abortion is still considered as ordinary as brushing one's teeth" (Pravoslavie.Ru 2016b).

When discussing abortion in light of the country's demographics, the prospect of a dwindling population and burgeoning numbers of potential migrants from Russia's neighboring states were securitized. At a joint press conference with state representatives titled "Russia for Life, Russia without Abortions", Hiermonk Dimitriy (Pershin) warned that "according to some estimates, [we have] around 5 years to turn things around. If this doesn't happen, then in 20 years, we'll have to hold a [press] conference in this very spot-in Chinese" (Smirnova 2011). Western Europe was used as a negative example of a barren land overrun by migrants. Archimandrite Dorofey (Vechkanov) cautioned that "if we [perform] abortions, then in 10 or 20 years, we will all be like in Europe ... there is nobody left to defend her. And thus all of Europe is filled with Arabs, Africans, or Turks" (Pravmir News Service 2016).

Frames with arguments about the country's laws regarding abortion were similar to those declaring abortion as murder in that they referenced the country's history. Hiermonk Dimitriy (Pershin) noted, "Before the [1917] Revolution, a doctor who performed abortions received 2 years in a prison colony" (Pershin and Ruonala 2012), while Priest Daniil Goryachev declared "We are in first place in the world-for legalization, since 1920, and for numbers of abortions" (Akhundova and Goryachev 2015). Others combined rationalinstrumental frames regarding current legal standards with religious frames referencing the Final Judgement (Matthew 25:31-46 NKJV): Archpriest Aleksiy Sukhikh warned that "According to secular law, they can give [sentences of] ten years and more for murder. But if they don't provide sentences for the destruction of a child, that doesn't mean that there isn't a Higher Court and that they can escape punishment" (Russkaya Narodnaya Liniya 2008).

When discussing social attitudes, speakers pointed to elements of what is known as "abortion culture" (Johnson 2004; Karpov and Kääriäinen 2005; Rivkin-Fish 2017) rooted in the Soviet past. Priest Oleg Bulychyov spoke of women who had gone through the "meat grinder" (Rivkin-Fish 2013, p. 573) of Soviet gynecology: "There are women (for some reason, there are a lot of them in villages) who don't know the total number of abortions they've had; after 10, they already lost track. And they have no regrets" (Bulychyov 2014b). Others referred to the materialism of the post-Soviet era, and rejection of parenthood on a global scale that included Russia. Archpriest Maksim Obukhov cautioned, "A lowering of the birthrate is a worldwide tendency that is not influenced by economic reasons alone. People are undergoing a change in their state of mind. They think that children are an unnecessary problem" (Cherevko 2012).

While religious framing supporting the concept of an embryo or fetus as a human being was rooted in belief in the presence of a soul bestowed by God, rational-instrumental frames were based in medical science. Priest Aleksandr Ilyashenko queried, "How does a child in the womb differ from one that has been born? Geneticists are convinced that the first cell (zygote) already contains full genetic information of a human being, that this, in fact, is a person" (Ilyashenko 2004b). The concept of the embryo and fetus as a human being capable of experiencing pain was used to frame abortions as an act of cruelty. Hiermonk and practicing medic Feodorit (Senchukov) argued that "Abortion is bad, even if you don't take the religious side [into account] ... It is painful for the child when he is dismembered. Sensitivity to pain forms early within an embryo" (Golovko 2017).

Another aspect of framing from a medical perspective was the rejection of abortion as a medical procedure on the grounds of the potential negative impact on women's physical and emotional health. Hiermonk Feodorit (Senchukov) contended, "Abortion is harmful, any gynecologist will confirm this. In the best of circumstances, it will not lead to benefits or noticeable harm; in the worst case, it can strike hard against a woman's health" (Senchukov 2016). Arguments regarding negative consequences for physical and 
mental health included references to a phenomenon called "post-abortion syndrome": Hiermonk Dimitriy (Pershin) used a combination of religious and medical terminology when warning about the impact of abortion on emotional and behavioral health, arguing that "A special term has been created for these pangs of conscience: 'post-abortion syndrome' - repentance that can lead to thoughts of suicide. Severe depression affects doctors who perform abortions as well" (Pershin 2010).

\subsection{Procedural and Church-State Relations Frames}

Of the 454 articles quoting Russian Orthodox clerics, and others serving in the Church using morality frames, 166 quoted speakers using procedural frames that had elements of church-state relations framing. Of these articles, 47 percent had a dominant disillusionment frame, 38 percent used an affinity dominant frame, 12 percent had a symphony dominant frame, and disestablishment frames lagged behind with only 3 percent (see Figure 4).

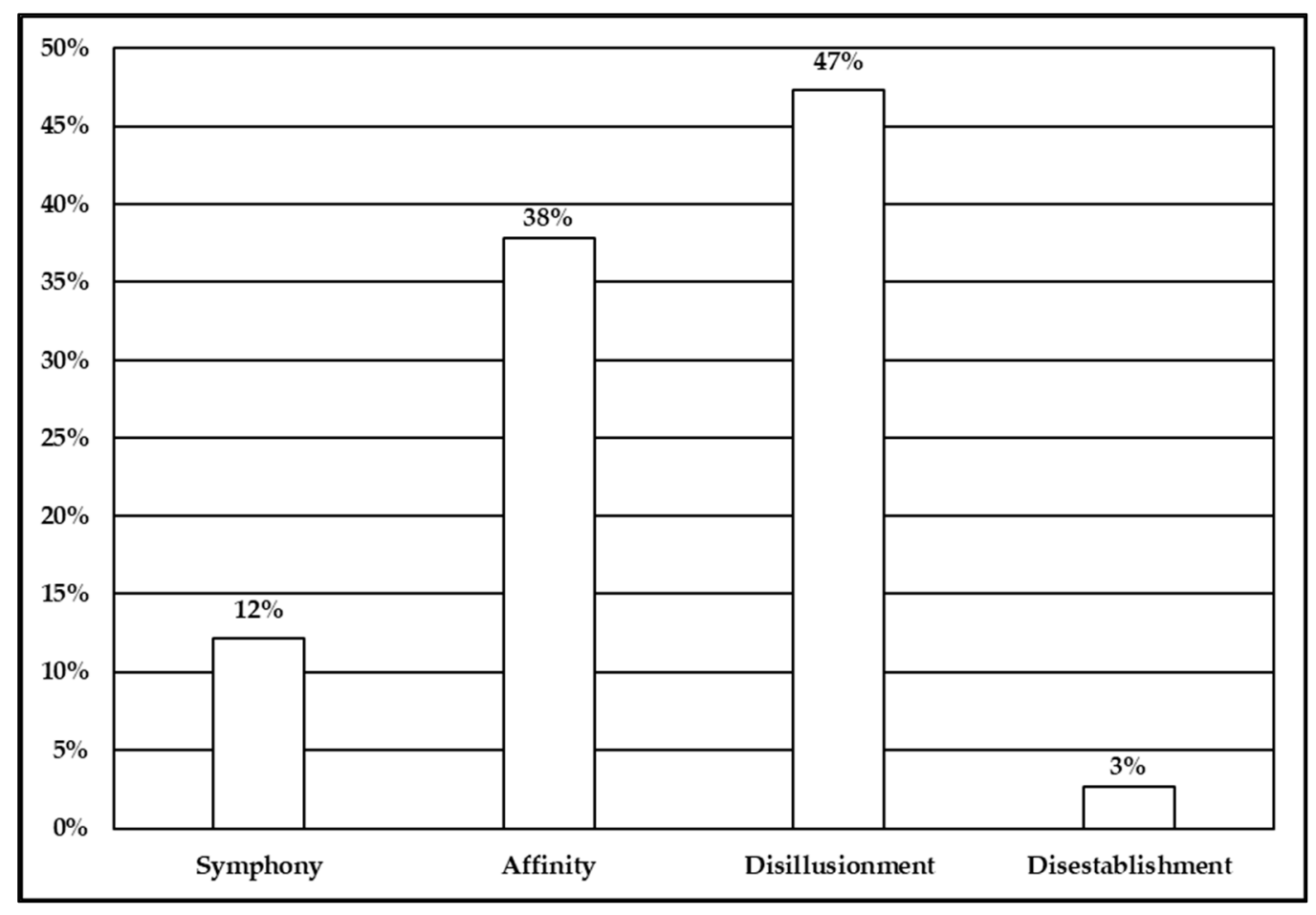

Figure 4. Dominant church-state relations frames, \% of articles where found.

Of the articles published on Pravoslavie.Ru that included church-state relations frames, the majority (45.8 percent) had a dominant affinity frame, with disillusionment taking second with 37.5 percent, symphony frames in third place with 12.5 percent, and disestablishment frames in fourth place with 4.2 percent. Among the articles including church-state relations frames published on Foma.Ru, the majority ( 40 percent) had a dominant disillusionment frame, while symphony, affinity, and disestablishment dominant frames were tied for second place with 20 percent each. Of the articles published on Pravmir.Ru, the majority of those that included church-state relations frames had dominant disillusionment frames with 50 percent, followed by affinity frames in second place with 33.8 percent, and symphony frames in third place with 14.9 percent; disestablishment frames sat in last place with only 1.4 percent. Among the articles published on Ruskline.Ru with church-state relations frames, disillusionment frames were in first place with 48.9 percent, followed closely by affinity frames with 42.2 percent. Symphony frames were in a distant third with 6.7 percent, and disestablishment frames were in last place with 2.2 percent (see Figure 5). 


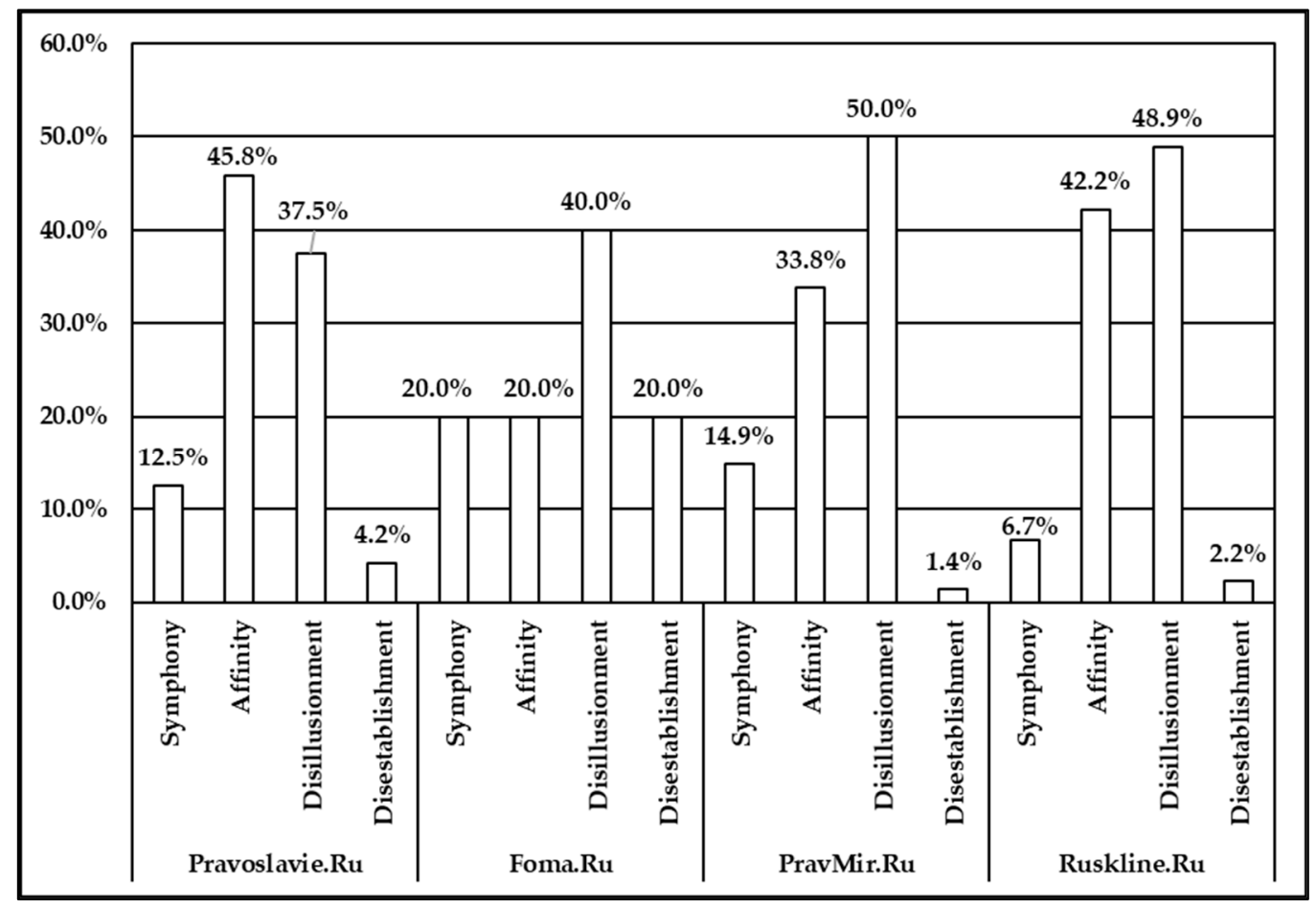

Figure 5. Dominant church-state relations frames, $\%$ of articles where found by portal.

\subsection{Symphony Frames}

Speakers who referred to (or called for) symphony between the ROC and the Russian state often saw collaboration as a necessary extension of the Church's work. Patriarch Kirill noted "Several years ago, I called for special attention to be paid to the problem of abortions in our country. Working with governors, with diocesan bishops, I began talking about the fact that urging women to refrain from this deadly act within church walls is not enough by itself" (Holy Patriarch of Moscow and All Rus Kirill 2017). Hegumen Nektariy (Morozov) saw this relationship in the sphere of curtailing the number of abortions performed as key to the nation's existence: "We try to cooperate with the authorities, we participate in joint programs with the state ... [and] we do not tire to mention that Orthodoxy is not only a culture-forming [religion], but, in fact, a state-building religion as well" (Morozov 2017).

One example of joint efforts was participation of clerics in the drafting of legislation. While the overall tone was optimistic, there were signs of caution as well. Archpriest Aleksiy Novikov made the case that "[The fact] that Church representatives take part in development of draft laws is correct and healthy", but followed this with a note of disillusionment, saying "This will underline and illuminate once again the opinion of the Church regarding key moments in the life of our people-an opinion that is often the exact opposite of that which dominates the minds of [state officials]" (Russkaya Narodnaya Liniya 2011).

Another sphere of cooperation was the installation of clerics in state-run medical facilities as part of efforts to intervene in cases where women wish to terminate a pregnancy. Metropolitan of Krutitskiy and Kolomna Yuvenaliy (Poyarkov) described this type of cooperation when arguing that:

The presence of a priest in the maternity ward, where young mothers are in great need of spiritual support and prayer, is especially important. A conversation between a pastor and a woman who intends to destroy her child in the womb can be truly life-changing. (Metropolitan of Krutitskiy and Kolomna Yuvenaliy 2014) 


\subsection{Dialogue Frames: Affinity}

The first of the two types of dialogue frame was affinity, where clerics and others serving in the Church praised activities by the state. This praise was often directed at national-level authorities following approval of key legislative measures. After the imposition of restrictions on advertisements of abortion clinics, Priest Aleksiy Volodin declared that "this is a big step forward for our government ... it is important insofar as the state has indicated its position. The state finally acknowledged abortions as an activity that brings harm to the nation" (Volodin 2009). Individual politicians were also lauded for speaking up against abortions in the public sphere. After Federation Council Chair Valentina Matviyenko declared that "Abortion is murder, and we must speak about this openly" at a meeting with regional women's organization leaders in 2015, Archpriest Mikhail Dudko commented that "Of course, it is gratifying that the main thought for any Christian sounded from the lips of a state functionary: it is forbidden to kill infants, whether or not they have been born yet" (Russkaya Narodnaya Liniya 2015).

Affinity frames also included statements of optimism that further actions would follow. Following the aforementioned imposition of restrictions on advertisements of abortion clinics, Archpriest Vsevolod Chaplin noted that "It's clear that our wishes were not entirely taken into account, but given the development of a negative relationship to abortion in society, which is forming not least thanks to the efforts of the Church, I hope that the state will be ready for more decisive measures" (Russkaya Narodnaya Liniya 2009). Years later, Chaplin referenced shifts in public opinion toward conservative values as another reason for state authorities to follow suit: "I want to hope that this approach to life, which is becoming more popular among people, including young people, will finally be confirmed in public order, rules, and laws" (Pravoslavie i Mir 2015).

\subsection{Dialogue Frames: Disillusionment}

The other side of the dialogue framing coin was disillusionment, wherein clerics and others serving in the Church expressed dissatisfaction with the state's policy priorities (particularly in regard to the medical system), non-delivery of social welfare benefits, and the behavior and personal character of state officials. One set of complaints targeted perceived inattentiveness of the state to freewheeling clinic advertisements and the activities of family planning organizations. Archbishop of Ufa and Sterlitamak Nikon (Vasyukov) opined that "now, when Russia is rapidly sliding into a demographic abyss, when ... the president has put forth the issue of increasing the birth rate, the ability of commercial abortion clinics to freely advertise infanticide looks strange" (Russkaya Narodnaya Liniya 2006). Deacon Andrey Kurayev ${ }^{1}$ declared that "I don't understand-how can one scream on every corner about a demographic crisis in the country and transport migrants here, [and] simultaneously allow the work of these 'Family Planning Centers'?" (Steshin 2006).

Complaints about the state medical system and mandatory state-run insurance program (OMS) centered on unfair divisions of financial resources by the former, and the fact that the latter is sponsored by taxpayers. Hegumen Serapion (Mitko) noted, "Many medical procedures that are important for one's health are excluded from this system. For example, it is very difficult to perform an operation for free, but it's easy to have an abortion" (Russkaya Narodnaya Liniya 2016). Archpriest Maksim Obukhov took exception to the way in which abortions are financed: "Rubles from the state budget are distributed for purchases of materials for chemical abortions. Our money is taken out of the budget for medicine, and goes toward financing of family planning centers that promote abortions and corrupt young people" (Obukhov 2011).

Another aspect of claims against the distribution of state funds was the failure of the state to properly fund and deliver state welfare benefits. Hiermonk Dimitriy (Pershin) maintained that "abortion on demand is funded out of the pocketbooks of all working Russians through the [OMS], but pregnant women in need don't receive financial assistance" (Pravmir Editorial Staff 2010b). Archpriest Maksim Obukhov dismissed benefits introduced on paper for families with multiple children as "dangling carrots that conceal a bunch of 
tricks and burdensome conditions" for eligibility (Borisova and Obukhov 2012). Archpriest Dimitriy Smirnov had a similarly doleful outlook on the situation: "[of the] proposals for aid to families with multiple children, only child benefit [payments are] guaranteed; everything else gets sabotaged" (Pravmir News Service and Archpriest Dimitriy Smirnov 2012).

Politicians who resisted placing further restrictions on abortion could be labeled as corrupt or morally flawed: Archpriest Dimitriy Smirnov remarked, “The abortion lobby that has money in this process is stronger than the will of the government to preserve our people" (Smirnov 2014). Archpriest Vsevolod Chaplin saw the roots of the issue as a much more personal affair: "Those who-publicly or behind the scenes-try to block Church initiatives aimed at lowering the number of abortions [performed] are often those who had abortions themselves and don't want their conscience to wake up in connection with this" (Danilova and Chaplin 2015).

\subsection{Disestablishment Frames}

While disestablishment frames were rare compared to the other church-state relations frames, they did give clues regarding sentiments that could translate into acts of civil disobedience. The specter of murder, including Russia's violent past, was raised to discredit the state. When queried about situations in which underage girls in orphanages were pressured to have abortions after falling pregnant, Archpriest Dimitriy Smirnov remarked, "it is hard to talk about this after the Nuremberg [Trials]. One of [our national] slogans proclaims that we are the country that conquered fascism. But much of what fascism consisted of flourishes [in Russia]" (Danilova and Smirnov 2020).

Another approach was to imply that not only was abortion murder, but politicians were happily complicit. While still a deputy in the St. Petersburg Legislative Assembly, then-altar server (now Subdeacon) Vitaliy Milonov discussed a failed attempt at adoption of a Constitutional amendment establishing that human life began at conception: "The [St.] Petersburg deputies spoke out against it, due to the fact that for the majority of them, it is far more pleasant to live [for] pleasure and kill children that you don't want to take care of" (Milonov 2013). Archpriest Dimitriy Smirnov had similar words to explain a lack of political will to approve greater restrictions on abortions: "This means that the government hasn't yet matured. A few million more children must be killed so that they will feel better, that we're dying out" (Pravoslavie.Ru 2016b). Elsewhere, Smirnov employed this and other arguments to contest the idea that the ROC supported the Russian state:

I personally criticize our state, which murders millions of children every year. With our taxes, at that. I mean abortions. I am very dissatisfied with the relationship of the state to families with multiple children, who are on the edge of survival [in Russia]. I think that it is an abusive relationship when an enormous quantity of documents is demanded so that the state will give a family with multiple children some kind of insignificant help. So there is no such thing as the 100 percent support of the state by the Church that you speak of. (Smirnov 2014)

\section{Conclusions}

When presenting arguments on abortion before the Russian public, clerics and others serving in the Russian Orthodox Church must grapple with two legacies of the Soviet system: the history of abortion as a preferred birth control method, and the fact that most self-declared Orthodox Christians are nominal and non-practicing. This study sought to adapt and apply a typology previously used in morality policy studies in the West to frames used by these speakers in Russian Orthodox online media sources.

The results showed that when providing commentary via religious media sources in the form of Russian Orthodox online portals, rational-instrumental frames were favored over those couched in religious principles. Even those arguing against abortions via portals run through a monastery (Pravoslavie.Ru) or led by laypeople with parallel executive positions in ROC institutions (Foma.Ru) still leaned heavily toward rational-instrumental framing, a communication style geared toward an audience whose level of religiosity is 
low. The fact that the one exception to the dominant rational-instrumental framing pattern in this study was the portal identified in prior research as being comparatively distant from the Moscow Patriarchate as an institution (Ruskline.Ru) is grounds for further inquiries as to why these frames were favored within this portal in particular.

The breakdown of results for church-state relations frames also held surprises both in terms of frames used and in which sources they were most prominent. The rarity of expressions of symphonia between the Church and Russian state raises doubts as to how seamless interactions between these two bodies truly are. The fact that speakers in three of the online portals surveyed mostly leaned toward disillusionment frames over those expressing affinity (with the one exception being the portal closest to the Moscow Patriarchate: Pravoslavie.Ru) indicates that there is a great deal of skepticism over whether the state is meeting the needs of the Church and its flock. On the other hand, the miserly figures for disestablishment frames that portrayed the state as the enemy of the Russian people point to a reluctance to sow discord with the authorities-at least not online.

Moving forward, the results for morality policy and church-state framing, and the breakdown between portals indicate that this research would benefit from an expansion of the data set. Examining morality framing of abortion by clerics and others serving in the Church via mainstream online news portals will shed light on whether similar framing patterns apply in a different media setting. Breaking down the analysis by article type (opinion pieces written by clerics, journalism on religion, and so on) would also help to determine the extent of editorial control over the choice of frames employed. In addition, the varied nature of framing strategies used between the portals points to a need for further study of editorial practices by the management of these and other Russian Orthodox online sources, in order to determine the extent to which commentators' framing strategies are influenced by publishing guidelines.

Funding: This research was funded by the Postsecular Conflicts Project, European Research Council grant number ERC STG 2015676804.

Acknowledgments: The author would like to thank Mia Lövheim and Kristina Stoeckl for their feedback in preparing this manuscript.

Conflicts of Interest: The author declares no conflict of interest.

\section{Note}

$1 \quad$ Kurayev was deposed from the priesthood in January 2021: http:/ / moseparh.ru/reshenie-eparxialnogo-suda-g-moskvy-podelu-50-54-2020.html (accessed on 7 December 2021).

\section{References}

Agadjanian, Alexander. 2001. Public Religion and the Quest for National Ideology: Russia's Media Discourse. Journal for the Scientific Study of Religion 40: 351-65. [CrossRef]

Akhundova, Irina, and Priest Daniil Goryachev. 2015. “Ya Slyshal Mnogo Ispovedey ob Aborte ot Zhenshchin i Ni Odnoy ot Muzhchin, Kotorye Prichestny k Nemu ... ": V Tsentre Zashchity Materinstva. Ruskline.Ru. Available online: http: //prod.ruskline.ru/analitika/2015/04/28/ya_slyshal_mnogo_ispovedej_ob_aborte_ot_zhenwin_i_ni_odnoj_ot_muzhchin_ kotorye_prichastny_k_nemu (accessed on 30 September 2021).

Beliakova, Ye.V., N.A. Beliakova, and Ye.B. Yemchenko. 2011. Zhenshchina v Pravoslavii: Tserkovnoe Pravo i Rossiyskaya Praktika. Moscow: Kuchkovo Polye, Available online: https:/ / azbyka.ru/otechnik/antropologiya-i-asketika/zhenshhina-v-pravoslavii-tserkovnoepravo-i-rossijskaja-praktika/ (accessed on 7 December 2021).

Bogdanova, Olga. 2020. Mediatization of Pastoral Care in the Russian Orthodox Church: Reasons behind "Ask the Priest" Websites. Gosudarstvo, Religiya, Tserkov v Rossii i Za Rubezhom 38: 207-34.

Bogdanova, Olga A., and A.S. Sokolov. 2020. Religious Mass Media Sources in a Convergence Situation: Instruments of Media Analysis and Forming a Strategy for "Foma" Orthodox Media in Social Networks. Vestnik VGU. Seriya: Filologiya. Zhurnalistika 4: 78-83. Available online: http:/ / www.vestnik.vsu.ru/pdf/phylolog/2020/04/2020-04-19.pdf (accessed on 7 December 2021).

Borisova, Aleksandra, and Archpriest Maksim Obukhov. 2012. Povysyat Li Novye Mery Vladimira Putina Rozhdayemost-Eksperty. Pravmir.Ru. Available online: https:/ / www.pravmir.ru/novye-mery-putina/ (accessed on 30 September 2021).

Bulychyov, Priest Oleg. 2014a. Detey Kaznit Nelzya Pomilovat. Pravoslavie.Ru. Available online: https://pravoslavie.ru/70346.html (accessed on 30 September 2021). 
Bulychyov, Priest Oleg. 2014b. Schastlivyy Betkhoven. Pravoslavie.Ru. Available online: https://pravoslavie.ru/71107.html (accessed on 30 September 2021).

Cherevko, Milena. 2012. Prot. Maksim Obukhov: "Nuzhno Pomoch Zhenshchine Sdelat Vybor v Polzu Rebyonka". Pravmir.Ru. Available online: https:/ / www.pravmir.ru/prot-maksim-obuxov-nuzhno-pomoch-zhenshhine-sdelat-vybor-v-polzu-rebenka/ (accessed on 30 September 2021).

Danilova, Anna, and Archpriest Vsevolod Chaplin. 2015. Protoierey Vsevolod Chaplin: Tretya Mirovaya Voyna Uzhe Idyot. Pravmir.Ru. Available online: https: / www.pravmir.ru/protoierey-vsevolod-chaplin-tretya-mirovaya-voyna-uzhe-idet/ (accessed on 30 September 2021).

Danilova, Anna, and Archpriest Dimitriy Smirnov. 2020. Protoierey Dimitriy Smirnov: Kozhu Snyat s Serdtsa. Pravmir.Ru. Available online: https: / / www.pravmir.ru/so-svoego-serdtsa-kozhu-snyat/ (accessed on 30 September 2021).

Denisov, Boris, and Victoria Sakevich. 2014. Abortion in Post-Soviet Russia: Is There Any Reason for Optimism? Demographic Review 1: 50-68. [CrossRef]

Entman, Robert M. 1993. Framing: Toward Clarification of a Fractured Paradigm. Journal of Communication 43: 51-58. [CrossRef]

Federal State Statistics Service. 2021. Vitrina Statisticheskikh Dannykh. Federalnaya Sluzhba Gosudarstvennoy Statistiki. Available online: https:/ / showdata.gks.ru/report/278930/ (accessed on 30 September 2021).

Flood, Patrick J. 2002. Abortion and the Right to Life in Post-Communist Eastern Europe and Russia. East European Quarterly 36: 191-226.

Fomin, Archpriest Igor. 2010. Aborty: Otvety na Neprostyye Voprosy. Pravmir.Ru. Available online: https://www.pravmir.ru/abortychto-mozhno-sdelat-uzhe-sejchas / (accessed on 30 September 2021).

Golovko, Oksana. 2017. Ieromonakh Feodorit (Senchukov): Posle Smerti Zheny Menya Spasli Docheri. Pravmir.Ru. Available online: https:/ / www.pravmir.ru/ieromonah-feodorit-senchukov-posle-smerti-zhenyi-menya-spasli-docherii/ (accessed on 30 September 2021).

Grafova, Maria. 2020. The Abortion in Soviet Russia during NEP: Official Propaganda versus Popular Attitudes. Gosudarstvo, Religiia, Tserkov' v Rossii i Za Rubezhom 38: 229-64. [CrossRef]

Grishaeva, Ekaterina. 2020. “Making Europe Great Again”: Anti-Western Criticism from Orthodox Conservative Actors Online. In Contemporary Russian Conservatism: Problems, Paradoxes, and Perspectives. Edited by Mikhail Suslov and Dmitry Uzlaner. Leiden: Brill, pp. 234-56.

Grishaeva, Ekaterina I., and Valeria A. Shumkova. 2018. Traditionalist Orthodox Christian Media: Discourse Structure and Peculiarities of the Functioning. Monitoring of Public Opinion: Economic and Social Changes 2: 291-308. [CrossRef]

Hill, Caroline. 2017. Framing "Gay Propaganda": The Orthodox Church and Morality Policy in Russia. Master thesis, Uppsala University, Uppsala, Sweden, January 31. Available online: http://uu.diva-portal.org/smash/get/diva2:1069954/FULLTEXT01. pdf (accessed on 7 December 2021).

Hjarvard, Stig. 2008. The Mediatization of Religion: A Theory of the Media as Agents of Religious Change. Northern Lights 6: 9-26. [CrossRef]

Hjarvard, Stig. 2012. Three Forms of Mediatized Religion: Changing the Public Face of Religion. In Mediatization and Religion: Nordic Perspectives. Edited by Stig Hjarvard and Mia Lövheim. Göteborg: Nordicom, pp. 21-44.

Hjarvard, Stig. 2016. Mediatization and the Changing Authority of Religion. Media, Culture E Society 38: 8-17.

Holy Patriarch of Moscow and All Rus Kirill. 2017. Vystupleniye na VII Obshchetserkovnom Syezde po Sotsialnomu Sluzheniyu. Pravoslavie.Ru. Available online: https: / / pravoslavie.ru/107569.html (accessed on 30 September 2021).

Ilyashenko, Archpriest Aleksandr. 2004a. Abort (Chast II). Pravmir.Ru. Available online: https://www.pravmir.ru/abort-chast-ii/ (accessed on 30 September 2021).

Ilyashenko, Archpriest Aleksandr. 2004b. Ne Nado Ubivat Svoikh Detey! Pravmir.Ru. Available online: https://www.pravmir.ru/nenado-ubivat-svoix-detej/ (accessed on 30 September 2021).

Ilyashenko, Archpriest Aleksandr. 2008. Zhenshchina Spasaetsya Chadorodiyem? Pravmir.Ru. Available online: https://www.pravmir. $\mathrm{ru} /$ zhenshhina-spasaetsya-chadorodiem/ (accessed on 30 September 2021).

Johnson, Kelley J. 2004. "New Thinking About an Old Issue": The Abortion Controversy Continues in Russia and Ireland—Could Roe v. Wade Have Been the Better Solution? Indiana International \& Comparative Law Review 15: 183-213.

Karpov, Vyacheslav, and Kimmo Kääriäinen. 2005. "Abortion Culture" in Russia: Its Origins, Scope, and Challenge to Social Development. Journal of Applied Sociology 22: 13-33. [CrossRef]

Kettell, Steven. 2017. The Collective Action Framing of Conservative Christian Groups in Britain. Politics and Religion 10: 286-310. [CrossRef]

Levada-Center. 2018. Tabu v Sfere Seksa i Reproduktsii. Levada-Tsentr. Available online: https://www.levada.ru/2018/01/11/17389/ (accessed on 30 September 2021).

Levada-Center. 2020. Velikiy Post i Religioznost. Levada-Tsentr. Available online: https://www.levada.ru/2020/03/03/velikij-post-ireligioznost/ (accessed on 30 September 2021).

Luchenko, Ksenia. 2015. Orthodox Online Media on Runet: History of Development and Current State of Affairs. Digital Icons: Studies in Russian, Eurasian and Central European New Media 14: 123-32. 
Luehrmann, Sonja. 2017. Innocence and Demographic Crisis: Transposing Post-Abortion Syndrome into a Russian Orthodox Key. In $A$ Fragmented Landscape: Abortion Governance and Protest Logics in Europe. Edited by Silvia De Zordo, Joanna Mishtal and Lorena Anton. Oxford: Berghahn Books, pp. 103-22.

Luehrmann, Sonja. 2019. "Everything New That Life Gives Birth To": Family Values and Kinship Practices in Russian Orthodox Antiabortion Activism. Signs: Journal of Women in Culture and Society 44: 771-95. [CrossRef]

Mason, Carol. 2019. Opposing Abortion to Protect Women: Transnational Strategy since the 1990s. Journal of Women in Culture and Society 44: 665-92. [CrossRef]

Metropolitan Ilarion [Alfeyev]. 2011. Imet ili Byt? Vliyaniye Seksualnoy Revolyutsii na Izmeneniye Nravstvennogo Klimata i Sotsialno-Ekonomicheskikh Otnosheniy v Sovremennom Mire. Pravmir.Ru. Available online: https://www.pravmir.ru/imet-ilibyt-vliyanie-seksualn/ (accessed on 30 September 2021).

Metropolitan of Krutitskiy and Kolomna Yuvenaliy. 2014. Mitropolit Krutitskiy Yuvenaliy: Sudbonosnoy Mozhet Stat Beseda Pastyrya s Zhenshchinoy, Kotoraya Namerevayetsya Pogubit vo Chreve Svoye Ditya. Pravmir.Ru. Available online: https:/ / www.pravmir.ru/mitropolit-krutitskiy-yuvenaliy-sudbonosnoy-mozhet-stat-beseda-pastyirya-s-zhenshhinoykotoraya-namerevaetsya-pogubit-vo-chreve-svoe-ditya/ (accessed on 30 September 2021).

Metropolitan of Ufa and Sterlitamak Nikon [Vasyukov]. 2006. Vrach Dolzhen Gorditsya Spasyonnymi Dushami, a Ne Ubitymi Detmi! Zayavleniye Ufimskogo Yeparkhialnogo Upravleniya Russkoy Pravoslavnoy Tserkvi. Ruskline.Ru. Available online: https:/ /ruskline.ru/analitika/2006/06/15/vrach_dolzhen_gordit_sya_spasennymi_dushami_a_ne_ubitymi_det_mi/ (accessed on 30 September 2021).

Milonov, Vitaliy. 2013. Vitaliy Milonov: V Pervuyu Ochered Neobkhodimo na Zakonodatelnom Urovne Priznat, Chto Abort-Eto Ubiystvo: Peterburgskiy Deputat o Zakonoproyekte Samarskoy Gubernskoy Dumy, Zapreshchayuschchem Finansirovaniye Abortov za Schyot Byudzheta. Ruskline.Ru. Available online: https://ruskline.ru/news_rl/2013/10/25/vitalij_milonov_v_ pervuyu_ochered_neobhodimo_na_zakonodatelnom_urovne_priznat_chto_abort_eto_ubijstvo/ (accessed on 30 September 2021).

Ministry of Health of the Russian Federation. 2011. Federalnyy Zakon ot 21 Noyabrya 2011g. No. 323-F3 “Ob Osnovakh Okhrany Zdorovya Grazhdan v Rossiyskoy Federatsii". In Ministerstvo Zdravookhraneniya Rossiyskoy Federatsii. Available online: https: // minzdrav.gov.ru/documents /7025-federalnyy-zakon-323-fz-ot-21-noyabrya-2011-g (accessed on 30 September 2021).

Mooney, Christopher Z. 1999. The Politics of Morality Policy: Symposium Editor's Introduction. Policy Studies Journal 27: 675-80. [CrossRef]

Morozov, Hegumen Nektariy. 2017. Igumen Nektariy (Morozov): “Revolyutsiya” v Tserkvi-Bunt protiv Khrista. Pravmir.Ru. Available online: https://www.pravmir.ru/igumen-nektariy-morozov-revolyutsiya-v-tserkvi-bunt-protiv-hrista/ (accessed on 30 September 2021).

Mucciaroni, Gary. 2009. Same Sex, Different Politics: Success and Failure in the Struggles over Gay Rights. Chicago: University of Chicago Press.

Mucciaroni, Gary. 2011. Are Debates about 'Morality Policy' Really about Morality? Framing Opposition to Gay and Lesbian Rights. The Policy Studies Journal 39: 187-216. [CrossRef]

Mucciaroni, Gary, Kathleen Ferraiolo, and Meghan E. Rubado. 2019. Framing Morality Policy Issues: State Legislative Debates on Abortion Restrictions. Policy Sciences 52: 171-89. [CrossRef]

Obukhov, Archpriest Maksim. 2011. A Vy Ikh Dustom Ne Probovali? Pravmir.Ru. Available online: https://www.pravmir.ru/a-vy-ixdustom-ne-probovali/ (accessed on 30 September 2021).

Pershin, Hiermonk Dimitriy. 2010. Zhurnal “Foma”: Povod k Dobru. Pravmir.Ru. Available online: https://www.pravmir.ru/zhurnalfoma-povod-k-dobru/ (accessed on 30 September 2021).

Pershin, Hiermonk Dimitriy, and Lidiya Ruonala. 2012. Ideologiya Smerti. Pravmir.Ru. Available online: https://www.pravmir.ru/ mipoteryali-naselenie/ (accessed on 30 September 2021).

Ponomariov, Alexander. 2015. The Body of Christ Online: The Russian Orthodox Church and (Non-)Liturgical Interactivity on the Internet. Digital Icons: Studies in Russian, Eurasian and Central European New Media 14: 145-63.

Ponomariov, Alexander. 2021. "In the Spirit of Symphony": On Russian Orthodox Church's Refinement of Secular Legal Standards in the Russian Federation. Interdisciplinary Journal for Religion and Transformation in Contemporary Society 7: 234-60. [CrossRef]

Pravmir Editorial Staff. 2010a. V Moskve Proshyol I Mezhdunarodnyy Festival Sotsialnykh Tekhnologiy v Zashchitu Semeynykh Tsennostey “ZA ZHIZN-2010”. Pravmir.Ru. Available online: https:/ /www.pravmir.ru/v-moskve-proshel-i-mezhdunarodnyjfestival-socialnyx-texnologij-v-zashhitu-semejnyx-cennostej-za-zhizn-2010/ (accessed on 30 September 2021).

Pravmir Editorial Staff. 2010b. “Meditsinskaya Gazeta”: Poshchadi Zhizn. Pravmir.Ru. Available online: https://www.pravmir.ru/ medicinskaya-gazeta-poshhadi-zhizn/ (accessed on 30 September 2021).

Pravmir News Service. 2014. Ieromonakh Dimitriy (Pershin): Yesli Zakony Protivorechat Zapovedyam, to My Dolzhny Menyat Zakony. Pravmir.Ru. Available online: https://www.pravmir.ru/ieromonah-dimitriy-pershin-esli-zakonyi-protivorechat-zapovedyamto-myi-dolzhnyi-menyat-zakonyi/ (accessed on 30 September 2021).

Pravmir News Service. 2016. Zhizni-Da, Abortam-Net! Pravmir.Ru. Available online: https://www.pravmir.ru/zhizni-da-abortamnet/ (accessed on 30 September 2021). 
Pravmir News Service and Archpriest Dimitriy Smirnov. 2012. Prot. Dimitriy Smirnov: Neobkhodima Yasnaya Tserkovnaya Programma Vozrozhdeniya Semyi. Pravmir.Ru. Available online: https://www.pravmir.ru/prot-dimitrij-smirnov-neobxodimayasnaya-cerkovnaya-programma-vozrozhdeniya-semi/ (accessed on 30 September 2021).

Pravoslavie i Mir. 2015. Problema Abortov: Proyavim Grazhdanskuyu Aktivnost! Pravmir.Ru. Available online: https:/ www.pravmir. ru/problema-abortov-proyavim-grazhdanskuyu-aktivnost/ (accessed on 30 September 2021).

Pravoslavie.Ru. 2016a. Protoierey Dmitriy Smirnov: Yesli My Ne Prekratim Sovershat Aborty, Gospod Sotryot Nas s Litsa Zemli. Pravoslavie.Ru. Available online: https:/ / pravoslavie.ru/99199.html (accessed on 30 September 2021).

Pravoslavie.Ru. 2016b. Ekspertnaya Gruppa pri Pravitelstve RF Otklonila Petitsiyu o Vyvedenii Abortov iz OMS. Pravoslavie.Ru. Available online: https:/ / pravoslavie.ru/99319.html (accessed on 30 September 2021).

Pravoslavie.Ru. 2019. Protoierey Aleksandr Ilyashenko: "Ya Prekrashchayu Vsyakoe Sotrudnichestvo s Pravmirom". Pravoslavie.Ru. Available online: https:/ / pravoslavie.ru/122365.html (accessed on 30 September 2021).

Regushevskaya, Elena, Tatiana Dubikaytis, Minna Nikula, Olga Kuznetsova, and Elina Hemminki. 2009. Contraceptive Use and Abortion among Women of Reproductive Age in St. Petersburg, Russia. Perspectives on Sexual and Reproductive Health 41: 51-58. [CrossRef]

RIA Novosti. 2009. Patriarkh Kirill Prizval Tserkov i Gosudarstvo k Vzaimodeystviyu. RIA Novosti. Available online: https: / / ria.ru/20090202/160741655.html (accessed on 30 September 2021).

RIA Novosti. 2019. Glavred "Pravmira" Prokommentirovala Ukhod Dukhovnika Portala. RIA Novosti. Available online: https: / / ria.ru/20190711/1556439423.html (accessed on 30 September 2021).

Rivkin-Fish, Michele. 2013. Conceptualizing Feminist Strategies for Russian Reproductive Politics: Abortion, Surrogate Motherhood, and Family Support after Socialism. Signs: Journal of Women in Culture and Society 38: 569-93. [CrossRef]

Rivkin-Fish, Michele. 2017. Legacies of 1917 in Contemporary Russian Public Health: Addiction, HIV, and Abortion. American Journal of Public Health 107: 1731-5. [CrossRef] [PubMed]

Russkaya Narodnaya Liniya. 2006. Abort: Pravo Vybora ili Pravo na Ubiystvo? Ruskline.Ru. Available online: https://ruskline.ru/ monitoring_smi/2006/06/28/abort_pravo_vybora_ili_pravo_na_ubijstvo/ (accessed on 30 September 2021).

Russkaya Narodnaya Liniya. 2008. Upovaya na Milost Bozhiyu: Kak Pravoslavnym Iskupat Grekh Soversheniya Aborta? Ruskline.Ru. Available online: https://ruskline.ru/monitoring_smi/2008/04/21/upovaya_na_milost_bozhiyu/ (accessed on 30 September 2021).

Russkaya Narodnaya Liniya. 2009. Protoierey Vsevolod Chaplin: "Sdelan Ochen Vazhnyy Shag v Pravilnom Napravlenii”. Ruskline.Ru. Available online: https://ruskline.ru/news_rl/2009/12/20091223/protoierej_vsevolod_chaplin_sdelan_ochen_vazhnyj_shag_ v_pravilnom_napravlenii/ (accessed on 30 September 2021).

Russkaya Narodnaya Liniya. 2010. Protoierey Aleksandr Shargunov: "Fakticheski Idyot Voyna na Unichtozheniye Naroda". Ruskline.Ru. Available online: https://ruskline.ru/news_rl/2010/10/18/protoierej_aleksandr_shargunov_fakticheski_idet_ vojna_na_unichtozhenie_naroda/ (accessed on 30 September 2021).

Russkaya Narodnaya Liniya. 2011. "Zhal, Chto u Nas Net Mekhanizma Otzyva Deputata": Svyashchennosluzhiteli Vyrazili Sozhaleniye v Svyazi s Tem, Chto Zdravye Mery, Predlagayemye Tserkovyu, Ne Nakhodyat Odobreniya v Gosdume. Ruskline.Ru. Available online: https://ruskline.ru/news_rl/2011/07/27/zhal_chto_u_nas_net_mehanizma_otzyva_deputata/ (accessed on 30 September 2021).

Russkaya Narodnaya Liniya. 2015. "Nuzhny Ne Zakonodatelnye Initiativy, a Dukhovno-Nravstvennye Orientiry": Izvestnye Pastyri o Merakh, Sposobnykh Povysit Rozhdaemost v Rossii. Ruskline.Ru. Available online: https://ruskline.ru/news_rl/2015/12/08 /nuzhny_ne_zakonodatelnye_iniciativy_a_duhovnonravstvennye_orientiry (accessed on 30 September 2021).

Russkaya Narodnaya Liniya. 2016. "Zashchita Zhizni Zachatogo Rebyonka-Uzhe Zadacha Obshchestva": Izvestnyye Pastyri o Predlozhenii Povysit Status Mnogodetnykh Semyey i Uzhestochit Antiabortnoye Zakonodatelstvo. Ruskline.Ru. Available online: https:/ / ruskline.ru/news_rl/2016/02/04/zawita_zhizni_zachatogo_rebenka_uzhe_zadacha_obwestva/ (accessed on 30 September 2021).

Russian Orthodox Church. 2008. Osnovy Sotsialnoy Kontseptsii Russkoy Pravoslavnoy Tserkvi. Russkaya Pravoslavnaya TserkovOfitsialnyy Sayt Moskovskogo Patriarkhata. Available online: http:/ / www.patriarchia.ru/db/text/419128.html (accessed on 30 September 2021).

Sakevich, Victoria I., and Boris P. Denisov. 2019. Reproduktivnoye Zdorovye Naseleniya i Problema Abortov v Rossii: Noveyshiye Tendentsii. Sotsiologicheskiye Issledovaniya 11: 140-51. [CrossRef]

Selinov, Pyotr, and Archpriest Andrey Ovchinnikov. 2016. Aborty Sovershayut Te, v Chyey Zhizni Otsutstvuyet Ponyatiye Grekha. Ruskline.Ru. Available online: https://ruskline.ru/monitoring_smi/2016/dekabr/2016-12-07/aborty_sovershayut_te_v_chej_ zhizni_otsutstvuet_ponyatie_greha/ (accessed on 30 September 2021).

Senchukov, Hiermonk Feodorit. 2016. Aborty: Chto Proiskhodit i o Chyom Prosit Patriarkh. Pravmir.Ru. Available online: https: //www.pravmir.ru/abort-s-prepyatstviyami1/ (accessed on 30 September 2021).

Smirnov, Archpriest Dimitriy. 2014. Otnosheniye Gosudarstva k Tserkvi Khuzhe, Chem u Tataro-Mongolov. Pravmir.Ru. Available online: https:/ / www.pravmir.ru/otnoshenie-gosudarstva-k-cerkvi-xuzhe-chem-u-tataro-mongolov/ (accessed on 30 September 2021).

Smirnova, Natalya. 2011. Pravo na Zhizn Podrazumevayet Pravo na Rozhdenie. Pravmir.Ru. Available online: https://www.pravmir. ru/pravo-na-zhizn-podrazumevaet-pravo-na-rozhdenie/ (accessed on 30 September 2021). 
Solodnikov, Vladimir V. 2010. Abortion. Sociological Research 49: 74-96. [CrossRef]

Staehle, Hanna. 2018a. Seeking New Language: Patriarch Kirill's Media Strategy. Religion, State E Society 46: $384-401$.

Staehle, Hanna. 2018b. Mediated Orthodoxy: The Russian Orthodox Church under Patriarch Kirill Facing Criticism in Digital Media. Doctoral Dissertation, University of Passau, Passau, Germany, March 29.

Steshin, Dmitriy. 2006. Rossii Obyavlena Demograficheskaya Voyna: Korrespondent "Komsomolki” Vyyasnil, Pochemu Rossiya Tak Bystro Vymirayet. Ruskline.Ru. Available online: https://ruskline.ru/monitoring_smi/2006/01/10/rossii_ob_yavlena_ demograficheskaya_vojna/ (accessed on 30 September 2021).

Stoeckl, Kristina. 2016. The Russian Orthodox Church as Moral Norm Entrepreneur. Religion, State E Society 44: 132-51.

Stoeckl, Kristina. 2018. Tri Modeli Tserkovno-Gosudarstvennykh Otnosheniy v Sovremennoy Rossii. Gosudarstvo, Religiya, Tserkov 36: 219-46.

Stoeckl, Kristina. 2020. Russian Orthodoxy and Secularism. Brill Research Perspectives in Religion and Politics 1: 1-75. [CrossRef]

Studlar, Donley T. 2008. U.S. Tobacco Control: Public Health, Political Economy, or Morality Policy? Review of Policy Research 25: 393-410. [CrossRef]

TASS. 2020. V Minzdrave Soobshili, Chto Kolichestvo Abortov v RF za Pyat Let Sokratilos Pochti na 30\%. TASS.Ru. Available online: https:/ / tass.ru/obschestvo/9826067 (accessed on 30 September 2021).

Volodin, Priest Aleksiy. 2009. Ierey Aleksiy Volodin: "Eto Pervyy Shag v Nuzhnom Napravleniy". Ruskline.Ru. Available online: https:/ / ruskline.ru/news_rl/2009/12/11/ierej_aleksij_volodin_eto_pervyj_shag_v_nuzhnom_napravlenii/ (accessed on 30 September 2021).

Yemelyanov, N. N. 2018. Paradoks Religioznosti: Otkuda Berutsya Veruyushchiye? Monitoring Obshchestvennogo Mneniya: Ekonomicheskie i Sotsialnyye Peremeny 2: 32-48. Available online: https:/ /wciom.ru/fileadmin/file/monitoring/2018/144/2018_144_02 Emelyanov.pdf (accessed on 8 December 2021).

Yerakhtina, Anna. 2013. Strana Ne Dolzhna Oplachivat iz Kazny Ubiystvo Sobstvennykh Grazhdan. Pravoslavie.Ru. Available online: http:/ / pravoslavie.ru/65916.html (accessed on 30 September 2021). 